Available online at

www.macvetrev.mk

Original Scientific Article

\title{
PRESENCE OF TRYPANOSOME SPECIES AND ANEMIC STATUS OF DOGS IN ZURU, NIGERIA
}

\author{
Rafi Rabecca Tono ${ }^{1}$, Olufemi Oladayo Faleke², Abdullahi Alhaji Magaji², \\ Musbaudeen Olayinka Alayande ${ }^{3}$, Akinyemi Olaposi Fajinmi ${ }^{4}$, \\ Emmanuel Busayo Ibitoye ${ }^{5}$
}

\author{
${ }^{1}$ Zonal Veterinary Clinic, Zuru Kebbi State, Nigeria \\ ${ }^{2}$ Department of Veterinary Public Health and Preventive Medicine, \\ Faculty of Veterinary Medicine, Usmanu Danfodiyo University Sokoto, Nigeria \\ ${ }^{3}$ Department of Veterinary Entomology and Parasitology, Faculty of Veterinary Medicine, \\ Usmanu Danfodiyo University Sokoto, Nigeria \\ ${ }^{4}$ Nigeria Institute of Trypanosomosis and Onchocerciasis Research, Kaduna, Nigeria \\ ${ }^{5}$ Department of Theriogenology and Animal Production, Faculty of Veterinary Medicine, \\ Usmanu Danfodiyo University Sokoto, Nigeria
}

Received 9 May 2015; Received in revised form 14 July 2015; Accepted 15 August 2015

\begin{abstract}
The aim of this research is to study the presence and prevalence of trypanosome species in local dogs between January and July, 2010 in the Zuru area of Kebbi State, Nigeria.Standard trypanosome detection methods comprising of wet blood films, thin films and microhaematocrit centrifugation technique were used to detect trypanosomes; while the degree of anemia was determined through the use of FAMACHA ${ }^{\circledR}$ eye colour chart and packed cell volume values. A total of 567 dogs were enumerated in fourteen locations within the study area out of which $192(33.7 \%)$ were randomly examined and $4(2.08 \%)$ were positive for the presence of trypanosomes. All positive samples morphologically belong to the Trypanosoma brucei group. The obtained PCV values showed that 50 (26.04\%) dogs were anemic, while the FAMACHA ${ }^{\circledast}$ detected anemia status of varying degrees in $104(77 \%)$ sampled dogs. These findings are significant as this is the first time that the trypanosome infection will be reported in dogs from the study area. This study establishes the presence of Trypanosoma brucei group in the study area, which is of zoonotic and economic importance.
\end{abstract}

Key words: anemia, dogs, Nigeria, trypanosomes, Zuru

\section{INTRODUCTION}

Trypanosomiasis is an important insect-borne protozoan disease and a serious constraint to livestock production and economic development in many parts of sub-Saharan Africa (1). It is widely distributed in tropical and subtropical regions and

Corresponding author: Dr. E.B. Ibitoye, DVM, MSc

E-mail address: emmavet2001@yahoo.com

Present address: Department of Theriogenology

and Animal Production, Faculty of Veterinary Medicine

Usmanu Danfodiyo University Sokoto, Nigeria

Phone: +2347038228200

Copyright: (C) 2015 Tono R.R.This is an open-access article published under the terms of the Creative Commons Attribution License which

permits unrestricted use, distribution, and reproduction in any medium, provided the original author and source are credited.

Competing Interests: The authors have declared that no competing

interests exist.

Available Online First: 1 September 2015

http://dx.doi.org/10.14432/j.macvetrev.2015.09.053 its epidemiology is determined by the ecology of its insect vector, the tsetse fly (Glossina spp). Canine trypanosomiasis is a devastating disease (2) characterized by anemia, severe weight loss, muscular weakness, abortion, corneal opacity, blepharitis, conjunctivitis, keratitis and death if untreated in affected dogs (3). Trypanosomiasis of dogs was first described in 1908 (4) and it is caused mainly by Trypanosoma brucei brucei (5), Trypanosoma congolense (6), Trypanosoma cruzi (7), Trypanosoma evansi (8) and Trypanosoma caninum (9). In Nigeria, trypanosomiasis in dogs due to T. brucei and T. congolense occurs more frequently (10). It has been established that different domestic animals including dogs are potential links for trypanosome exchange between livestock and humans i.e. Trypanosome brucei gambiense and Trypanosome brucei rhodesiense, 
causing a condition known as HAT, also referred to as 'sleeping sickness $(11,12,13)$, while $T$. brucei brucei causes severe to fatal infections in horses, camels, dogs and cats (14).

There has been increased interest in keeping dogs in Nigeria, mainly as security or pets, and in some parts of the country for food. Similarly, the proceeds from the sales of dogs serve as additional income for the owners (15). Though dogs are known to pose minimal risk for human infection (HAT), they are important as a sentinel for infection (13). Canine trypanosomiasis has been reported as constituting a major health threat to canine population in the south-eastern part of Nigeria $(10,11,16)$.

The study area is an interface between the hitherto declared 'tsetse-free' zone of the northwest and tsetse endemic areas southward in the middle belt of Nigeria. The people in the study area are predominantly crop farmers whose activities are restricted to the short period of rainfall. The long dry season is used mainly for hunting in which the expeditions takes them south, where tsetse flies abound (17). The study therefore investigated possible incursion of trypanosomes to the study area through dogs.

\section{MATERIAL AND METHODS}

\section{Study Area}

The study was undertaken in the Zuru Local Government Area, south-eastern part of Kebbi State, northwest, Nigeria. It lies within latitudes $11^{0} 15^{\prime}$ to $11^{0} 55^{\prime} \mathrm{N}$ and longitudes $4^{0} 35^{\prime}$ to $5^{0} 47 \mathrm{E}$ and falls within the Sudan Savannah type of vegetation, with a mean annual rainfall of $1022 \mathrm{~mm}$ and a mean minimum and maximum temperatures of $24.6^{\circ} \mathrm{C}$ and $28^{\circ} \mathrm{C}$ respectively. The dominant group is the Lelna people whose economic activities center on crop and livestock production, with some engaging in hunting expeditions southward towards Niger and Kwara States of Nigeria. A preliminary census of household dog population was conducted in 14 selected locations using a purposive sampling method, while the dogs were sampled by a convenience sampling technique. Within the study area a representative sample size was determined using the formula: $n=Z^{2} P Q / L^{2}$. Where $n=$ number of individuals; $\mathrm{Z}=$ the $\mathrm{Z}$ score for a given confidence interval (95\%); for this study, since there was no known prevalence for canine trypanosomiasis in the study area, P was estimated at 20\%; Q $=1-$ P and $\mathrm{L}=$ is the allowable error of estimation (5\%) (18). Using this formula, 167 dogs are to be sampled but 218 this was increased to 192 so as to increase precision. Dogs from a dog market within the study area were also sampled. Structured questionnaire comprising of information on dog usage and maintenance was designed and administered to owners in the sampled households only in relation to the veterinary health care delivery system.

About $3 \mathrm{ml}$ of blood was collected from the cephalic vein from each of the dogs that were sampled, using $5 \mathrm{ml}$ sterile syringe and needle and transferred into clean EDTA bottles. The blood in each bottle was gently mixed, placed in a cool box containing ice packs and transported in about $2 \mathrm{hrs}$ to the Veterinary Public Health and Preventative Medicine laboratory of Usmanu Danfodiyo University Sokoto, Nigeria for immediate analysis. The blood samples were then examined using the standard trypanosome diagnostic methods (STDM) comprising of wet blood films, thin films and microhaematocrit centrifugation technique (19, 20). Morphological identification of trypanosomes was carried out using Giemsa stained films. Packed cell volume (PCV) was determined to detect level of anemia [normal PCV range 36 - 55\%] (21), while FAMACHA $^{\circledR}$, an eye colour chart with five colourscores [scores: 1=optimal, no anemia; $2=$ acceptable, no anemia; $3=$ borderline, moderate; $4=$ dangerous, anemic and 5=fatal, anemic] (22) were used to diagnose different levels of anemia.

\section{Ethical approval}

Ethical clearance as approved by the Research Ethical Committee of the Faculty of Veterinary Medicine, Usmanu Danfodiyo University Sokoto, Nigeria was obtained prior to this study.

\section{Statistical Analysis}

Descriptive statics was used to analyze data (23).

\section{RESULTS}

Preliminary census enumerated a total number of 510 Nigerian local breed of dogs from households in 14 locations namely: Bayan Tasha, Filin Jirgi, Gomawa, Jarkasa, Low cost, Mangorori, Rikoto, Roadblock, Sabuwar Kasuwar, Sha da Wanka, Tudun Wadata, Unguwar Zuru, Zango, Zuru Center and a dog market. As shown in Table 1, Rikoto had the highest number of dogs $(n=77)$, while Mangorori had the lowest $(n=11)$. A total of 192 Nigerian dogs were selected comprising of $135 \mathrm{dogs}$ from the households and 57 dogs from the dog market. 
Trypanosome species and anemic status at dogs

Table 1. Dog population structure with the number of sampled and positive cases in households and dog market in Zuru area, Kebbi State

\begin{tabular}{lcccc}
\hline Location & Enumerated & Sampled No. & $\begin{array}{c}\text { Percentage } \\
\text { sampled (\%) }\end{array}$ & Positive samples \\
\hline Bayan Tasha & 18 & 5 & 27.8 & - \\
Dog market & 57 & 57 & 100.0 & 1 \\
Filin Jirgi & 42 & 11 & 26.2 & 1 \\
Gomawa & 27 & 6 & 22.2 & - \\
Jarkasa & 46 & 13 & 28.3 & - \\
Low Cost & 27 & 6 & 22.2 & - \\
Mangorori & 11 & 3 & 27.3 & - \\
\hline Rikoto & 76 & 22 & 28.9 & 1 \\
Roadblock & 39 & 10 & 25.6 & - \\
Sabuwar Kasuwa & 41 & 11 & 26.8 & - \\
Sha da wanka & 42 & 10 & 26.2 & - \\
Tudun Wadata & 39 & 14 & 25.6 & - \\
Unguwar Zuru & 49 & 5 & 28.6 & - \\
Zango & 20 & 8 & 25.0 & - \\
Zuru Centre & 33 & $\mathbf{1 9 2}$ & 24.2 & $\mathbf{4 ( 2 . 0 8 \% )}$ \\
\hline Total & $\mathbf{5 6 7}$ & & $\mathbf{3 3 . 7}$ & \\
\hline
\end{tabular}

Out of 192 blood samples analyzed by STDM, $4(2.08 \%)$ were positive for trypanosomes. Out of these wet blood film detected all the 4 positive cases, microhaematocrit detected 3, while Giemsa stain (thin blood) technique detected 2 (Table 2).
The PCV values ranges and FAMACHA scores of all sampled animals were not consistent with their anemic statuses. According to PCV values, of the 192 dogs examined 50 (26.04\%) dogs were anemic (21), with $3(1.56 \%)$ being positive for trypanosomes

Table 2. Distribution of positive samples and anemic indicator values

\begin{tabular}{lcccccccc}
\hline Areas & PCV (\%) & WBC & RBC (\%) & Hb & $\begin{array}{c}\text { FAMACHA } \\
\text { Score }\end{array}$ & Wet blood & Haematocrit & Thin blood \\
\hline Dog market & 34 & 12.40 & 3.10 & 10.3 & NC & + & + & + \\
\hline Filin Jirgi & 32 & 10.02 & 3.23 & 10.7 & 4 & + & + & + \\
Rikoto & 36 & 4.88 & 5.43 & 12.0 & 4 & + & + & - \\
\hline Unguwar Zuru & 24 & 3.25 & 4.73 & 8.0 & 4 & + & - & + \\
\hline Key: $\boldsymbol{N C}=$ Not conducted & & & & & & & + \\
\hline
\end{tabular}

Morphologically, all the positive samples were identified to be in the Trypanosoma brucei group (Fig. 1).

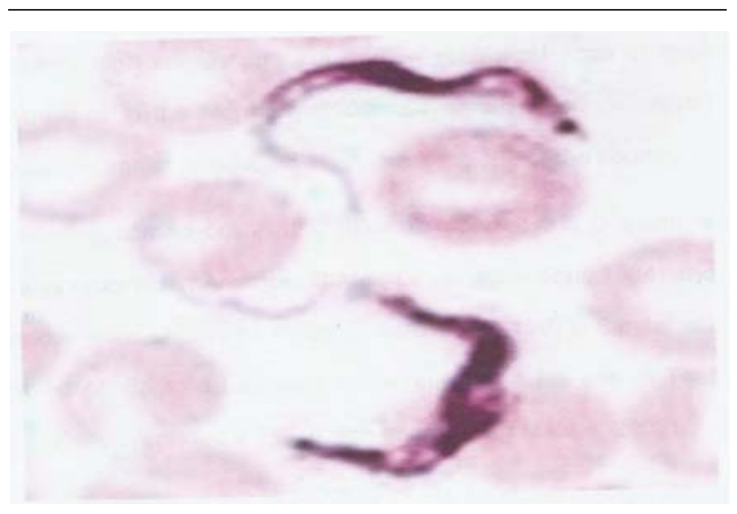

Figure 1. Giemsa stained Trypanosomabruceion thin film smear and $47(24.47 \%)$ negative for trypanosome infection, while out of 142 (73.95\%) non-anemic dogs, $1(0.52 \%)$ was positive for trypanosomes and $141(73.43 \%)$ were negative (Table 3$)$. Of the 135 household-dogs sampled, FAMACHA ${ }^{\circledR}$ gave a total of $104(77 \%)$ dogs with anemia. FAMACHA ${ }^{\circledR}$ testing was not done for dogs from the dog market (Table 4).

All the 135 respondents claimed that their dogs were kept mainly for security purposes and it was observed that dogs were mostly unleashed and found roaming about in the study area. As shown on Table 5, 21 (15.6\%) of the respondents feed their dogs occasionally, $74(54.8 \%)$ did not vaccinate their dogs against any disease, only $5(3.7 \%)$ have their dogs receive regular veterinary health care services, while 53 (39.3\%) have dogs infested with ticks and $86(63.7 \%)$ having to dispose their dogs 
Tono R.R. et al.

Table 3. Anemic status of examined dogs at different locations in Zuru using PCV

\begin{tabular}{|c|c|c|c|c|c|}
\hline \multirow{2}{*}{ Locations } & \multicolumn{2}{|c|}{ Trypanosomal negative } & \multicolumn{2}{|c|}{ Trypanosomal positive } & \multirow{2}{*}{ Total } \\
\hline & Anemic & Non- anemic & Anemic & Non- anemic & \\
\hline Bayan Tasha & 2 & 3 & - & - & 5 \\
\hline Dog market & 2 & 36 & 1 & - & 57 \\
\hline Filin Jirgin & 2 & 8 & 1 & - & 11 \\
\hline Gomawa & 2 & 4 & - & - & 6 \\
\hline Jarkasa & 1 & 12 & - & - & 13 \\
\hline Low Cost & 0 & 6 & - & - & 6 \\
\hline Mangorori & 2 & 1 & - & - & 3 \\
\hline Rikoto & 6 & 15 & - & 1 & 22 \\
\hline Roadblock & 1 & 9 & - & - & 10 \\
\hline SabuwarKasuwa & 2 & 9 & - & - & 11 \\
\hline Sha da wanka & 3 & 8 & - & - & 11 \\
\hline Tudun Wadata & 0 & 10 & - & - & 10 \\
\hline Unguwar Zuru & 1 & 12 & 1 & - & 14 \\
\hline Zango & 2 & 3 & - & - & 5 \\
\hline Zuru Centre & 3 & 5 & - & - & 8 \\
\hline Total & $47(24.47 \%)$ & $141(73.43 \%)$ & $3(1.56 \%)$ & $1(0.52 \%)$ & 192 \\
\hline
\end{tabular}

Table 4. Anemic status of examined dogs at different locations in Zuru using FAMACHA ${ }^{\circledR}$

\begin{tabular}{|c|c|c|c|c|c|}
\hline \multirow[t]{2}{*}{ Locations } & \multicolumn{2}{|c|}{ Trypanosomal negative } & \multicolumn{2}{|c|}{ Trypanosomal positive } & \multirow[t]{2}{*}{ Total } \\
\hline & Anemic & Non-Anemic & Anemic & Non- anemic & \\
\hline Bayan Tasha & 5 & 0 & - & - & 5 \\
\hline Dog market & $\mathrm{NC}$ & $\mathrm{NC}$ & $\mathrm{NC}$ & $\mathrm{NC}$ & $\mathrm{NC}$ \\
\hline Filin Jirgin & 5 & 5 & 1 & - & 11 \\
\hline Gomawa & 6 & 0 & - & - & 6 \\
\hline Jarkasa & 7 & 6 & - & - & 13 \\
\hline Low Cost & 4 & 2 & - & - & 6 \\
\hline Mangorori & 3 & 0 & - & - & 3 \\
\hline Rikoto & 13 & 8 & 1 & 0 & 22 \\
\hline Roadblock & 9 & 1 & - & - & 10 \\
\hline SabuwarKasuwa & 11 & 0 & - & - & 11 \\
\hline Sha da wanka & 11 & 0 & - & - & 11 \\
\hline Tudun Wadata & 7 & 3 & - & - & 10 \\
\hline Unguwar Zuru & 11 & 2 & 1 & - & 14 \\
\hline Zango & 3 & 2 & - & - & 5 \\
\hline Zuru Centre & 6 & 2 & - & - & 8 \\
\hline Total & $101(74.81 \%)$ & $31(22.96 \%)$ & $3(2.22 \%)$ & $0(0.0 \%)$ & 135 \\
\hline
\end{tabular}

Table 5. Responses to the questionnaire survey on dog management within Zuru

\begin{tabular}{llll}
\hline Sampled questions & No. of Responses & & \\
\hline Purpose for keeping dog & Security 135(100\%) & Commercial (Nil) & Hobby/Pet (Nil) \\
Duration of keeping dog sampled & 1 month-1 year 12(9.8\%) & $2-5$ years 31(23.0\%) & 6 year and above 93(68.9\%) \\
& More than once & Once daily & Some times \\
Mode of feeding & $92(68.2 \%)$ & $22(16.3 \%)$ & $21(15.6 \%)$ \\
& Regularly & Sometimes & Not at all \\
Anti-rabies vaccination & $5(3.7 \%)$ & $56(41.5 \%)$ & $74(54.8 \%)$ \\
Acquaintance with veterinary & Regularly & Sometimes & Not at all \\
services & $5(3.7 \%)$ & $64(47.4 \%)$ & $66(48.9 \%)$ \\
Preference to sex during purchase & Yes 6(4.4\%) & & No 129(95.6\%) \\
Owing other breeds & Yes 3(2.2\%) & & No 132(97.8\%) \\
Reasons leading to dog disposal & Harassment & Illness $86(63.7 \%)$ & Accidents \\
Presence of ectoparasites & $23(17.0 \%)$ & & No 82(60.7\%) \\
\hline
\end{tabular}


Trypanosome species and anemic status at dogs

due to illness. Virtually all adult dogs were involved in hunting expedition during the dry season period. The hunting for game animals goes beyond the boundary of Zuru Emirate, it extends southwards into Niger and some parts of Kwara States, Nigeria.

\section{DISCUSSION}

There is little information on canine trypanosomiasis in Nigeria and its epidemiology is poorly understood. In the study area and its environs, there are no previous prevalence studies making this study a preliminary study. When compared with prevalence obtained in endemic parts of Nigeria, the obtained prevalence of $2.08 \%$ in this study could be considered higher and calls for concern as the study area is previously known to be free of trypanosomes. According to other studies, the prevalence of trypanosomiasis in dogs was 3\% in Jos Plateau (24), $8.8 \%$ in two veterinary clinics in Anambra State (10) and $10 \%$ in Nsukka area of Enugu State (11). The detection of Trypanosoma brucei trypanosomes in the current study is in agreement with Anene et al. (11); Abenga et al. (12); Omamegbe et al. (10) and Anene et al. (16), who reported that Trypanosoma brucei is the predominant species involved in canine trypanosomiasis in Nigeria. The presence of trypanosomes in the study area can be attributed to factors such as the unrestricted movement of dogs through commercial purposes, hunting expeditions into endemic areas and existence of Glossina palpalis palpalis both in the wet and dry seasons in areas where hunting expeditions normally take place (17).

Anemia is one of the pathogenic consequences of trypanosomiasis (22). However, the high percentage of the animals showing various levels of anemia may be due to extraneous factors such as the state of nutrition, the presence of other inter-current infections such as helminthes, which is a common problem of developing countries and ubiquitous in livestock and other domestic animals (25) and stress caused by long trekking and distant transportation. From PCV values and FAMACHA ${ }^{\circledR}$ scores, all dogs infected with trypanosomes were anemic except in one dog, with PCV of $36 \%$ but a FAMACHA ${ }^{\circledR}$ score of 4 . This inconsistency may be as a result of haemoconcentration in the animal (26), or could also indicate recent infection. The leucopenia observed in two of the positive samples (Rikkoto and Unguwar Zuru) could be an indication of early infection (27), but the normal leucocyte counts from the other two positive samples from the Dog market and Filin Jirgi could not be explained.

\section{CONCLUSION}

Findings of this study establish the presence of Trypanosoma brucei group in dogs which were found in a free-HAT zone and they pose a risk for human and livestock health. Morphologically, Trypanosoma brucei brucei and Trypanosoma brucei gambiense are indistinguishable. Therefore molecular testing is suggested in further studies in order to confirm if Trypanosoma brucei gambiense is present in the population. Also, appropriate measures which include public health awareness and improvement on veterinary health care delivery services be made more readily available in the study area.

\section{ACKNOWLEDGEMENT}

The authors are thankful to the authorities of the Department of Veterinary Public Health and Preventive Medicine, Faculty of Veterinary Medicine, Usmanu Danfodiyo University Sokoto, Nigeria, for the permission to use the departmental laboratory and equipment to carry out this investigation. All authors contributed financially.

\section{REFERENCES}

1. Ilemobade, A.A. (2009). Tsetse and trypanosomosis in Africa: the challenges, the opportunities. Onderstepoort J Vet Res, 76, 35-40.

http://dx.doi.org/10.4102/ojvr.v76i1.59

PMid:19967926

2. Abenga, J.N., Ezebuiro, C.O., David, K., Fajinmi, A.O., Samdi, S. (2005a). Studies on anemia in Nigerian local puppies infected with Trypanosoma congolense. Veterinarski Arhiv, 75, 165-174.

3. Stephen, E.L. (1986). Trypanosomiasis; a veterinary perspective. In Wheaton \& Co. Ltd. Exter. (Ed). (pp. 235-314).

4. Bevan, E.W. (1913). Preliminary notes on a trypanosome causing disease in man and animal in the Sebungwe district of southern Rhodesia. J. Trop. Med. Hyg., 16, 113-117.

5. Simo, G., Njitchouang, G.R., Njiokou, F., Cuny, G., Asonganyi, T. (2012). Genetic characterization of Trypanosoma brucei circulating in domestic animals of the Fontem sleeping sickness of Cameroon. Microbes and Infection / Institut Pasteur, 14, 651-658. http://dx.doi.org/10.1016/j.micinf.2012.02.003 PMid:22387499

6. Desquesnes, M., Ravel, S., Deschamps, J.Y., Polack, B., Roux, F. (2012). A typical hyperpachymorph Trypanosoma (Nannomonas) congolense forest-type in a dog returning from Senegal. Parasite, 19, 239-247.

http://dx.doi.org/10.1051/parasite/2012193239 PMid:22910666 PMCid:PMC3671449 
7. Quijano-Hernandez, I.A., Castro-Barcena, A., Barbabosa-Pliego,A., Ochoa-Garcia,L.,Angel-Caraza, J.D., Vázquez-Chagoyán, J.C. (2012). Seroprevalance survey of American Trypanosomiasis in Central Valley of Toluca. Scientific World Journal, 450, 619. http://dx.doi.org/10.1100/2012/450619 PMid:22649293 PMCid:PMC3353279

8. Defontis, M., Richard, J., Engelmann, N., Bauer, C., Schwierk, V.M., Buscher, P., Moritz, A. (2012). Canine Trypanosoma evansi infection introduced into Germany. Vet. Clin. Path., 41, 369-374.

http://dx.doi.org/10.1111/j.1939-165X.2012.00454.x PMid:22954298

9. Rodrigo, C.M., Fabiano, B.F., Annabel, G.W., Maria, F.M., Raquel, V.C.O., Tânia, M.P.S., Matti, K., Ingeborg, M.L. (2013). Sensitivity and specificity of in situ hybridization for diagnosis of cutaneous infection by Leishmania infantum in dogs. J.Clin. Microbiol., 51, 206-211.

http://dx.doi.org/10.1128/JCM.02123-12

PMid:23135932 PMCid:PMC3536224

10. Omamegbe, J.O., Orajaka, L.J.E., Omehelu, C.O. (1984). The incidence and clinical forms of naturally occurring canine trypanosomosis in two vet clinics in an Anambra State of Nigeria. Bull Animal Hith Prod Africa, 32, 23-29.

11. Anene, B.M., Obetta, S.S., Agu, W.E. (1997). Prevalence of canine trypanosomosis with regards to dog and owners characteristics in Nsukka area of Enugu State, Nigeria. Nig. Vet. J., 18, 306-310.

12. Abenga, J.N., David, K., Ezebuiro, C.O.G., Lawani, F.A.G. (2005). Observation on the prevalence of young dogs (puppies) to infection with Trypanosoma congolense. African Journal of Clinical Experimental Microbiology, 6, 28-33.

13. Museux, K., Boulouha, L., Majani, S., Journaux, H. (2011). African Trypanosoma infection in dog in France. Veterinary Records, 168: 590b.

http://dx.doi.org/10.1136/vr.d888 PMid:21622597

14. African Trypanosomiasis http://www.vet.uga.edu/vpp/gray_book/Handheld/ aat.htm

15. Oboegbulem, I.S. (1994). Rabies in man and animals. Fidelity publishers and printer Co. Ltd. Enugu. Pp. 41-42.

16. Anene, B.M., Ezeokonkwo, R.C., Mmesirionye, T.I., Tettey, J.N.A., Brock, J.M., Barret, M.P., De Koning, H.P. (2005). A diaminazine resistant strain of Trypanosoma brucei isolated from a dog is cross resistant to pentamidine in experimentally infected albino rats. Parasitology, 132, 127-133. http://dx.doi.org/10.1017/S0031182005008760 PMid:16393361
17. Ahmed, A.B. (2004). A peridomestic population of the tsetse flies Glossina palpalis palpalis. RobinneauDesvoidy, 1830 (Diptera: Glossinidae) at Kotongora town, Niger State, Nigeria. Entomología Vectores, 11, 599-610. http://dx.doi.org/10.1590/S0328-03812004000400004

18. Martin, S.W., Meek, A.H., Willeberg, P. (1987). Veterinary epidemiology, principle and methods. Iowa State University Press, pg. 343.

19. Woo, P.K.T. (1969). The haematocrit centrifugation for the detection of trypanosomes in blood. Can. J. Zoolog., 47, 921-923. http://dx.doi.org/10.1139/z69-150

20. World Organization of Animal Health (2004). Manual of diagnosis tests and vaccines for terrestrial animals, $5^{\text {th }}$ edition, part 2, section 2, 3 and 15 .

21. Hassan, A.Z., Hassan, F.B. (2003). Basic Clinic Services. In: An Introduction to Veterinary Practice. 1st Ed. p. 57.

22. Grace, D., Himstedt, H., Sidibe, I., Randolph, T.H., Clausen, P. (2007). Comparing FAMACHA ${ }^{\circledR}$ eye colour chart and Haemoglobin colour scale tests for detecting anemia and improving treatment of bovine trypanosomosis in West Africa. Acta Trop. Aug; 111(2):137-43.

http://dx.doi.org/10.1016/j.actatropica.2009.03.009. PMID: 19524082

23. Anthony, E.O. (2005). Biostatistics: A practical approach to research and data handling. Mindex Press, Ugbowo, Benin City, Nigeria

24. Fajinmi, O.A. (2008). Epidemiology of animal trypanosomosis in Sokoto State, Nigeria. A MVPH Dissertation Report, Faculty of Veterinary Medicine, Usmanu Danfodiyo University, Sokoto, p. 139.

25. Kerboeuf, D., Blackhall, W., Kaminsky, R., SamsonHimmelst Jerna, G.V. (2003). P-glycoprotein in helminthes. Function and perspectives for anthelminthic treatment and reversal of resistance. Int. J. Parasitol., 22, 332-346.

26. Evans, S.F., Hinds, C.J., Varley, J.G. (1984). A new canine model of endotoxin shock. Brit J Pharmacol., 83 (2):433-442.

http://dx.doi.org/10.1111/j.1476-5381.1984.tb16504.x PMid:6435710; PMCid:PMC1987104

27. Mackenzie, P.K.I., Boyt, W.P., Nesham, V.M., Pirie, E. (1983). The aetiology and significance of the phagocytosis of erythrocytes and leucocytes in sheep infected with Trypanosoma congolense (Broden, 1904). Research in Veterinary Science, 24, 4-7.

Please cite this articl as: Tono R.R., Faleke O. O., Magaji A.A., Alayande M.O., Fajinmi A.O., Ibitoye E.B. Presence of trypanosome species and anemic status of dogs in Zuru, Nigeria. Mac Vet Rev 2015; 38 (2): 217-222. http://dx.doi.org/10.14432/j.macvetrev.2015.09.053 